\title{
Identifikasi Peptida Bioaktif dari Protein Kedelai sebagai Inhibitor Enzim a-glukosidase untuk Kandidat Antidiabetes
}

\section{Identification of Bioactive Peptides from Soy Protein as an $\alpha-$ glucosidase Enzyme Inhibitor for Antidiabetic Candidates}

\author{
Taufik Muhammad Fakih*, Mentari Luthfika Dewi \\ Program Studi Farmasi, Fakultas Matematika dan Ilmu Pengetahuan Alam, Universitas Islam Bandung, \\ Bandung, Indonesia \\ *E-mail: taufikmuhammadf@gmail.com
}

Received: 1 April 2020; Accepted: 24 Desember 2020; Published: 31 Desember 2020

\begin{abstract}
Abstrak
Diabetes mellitus merupakan salah satu gangguan metabolisme endokrin yang telah menyebabkan morbiditas dan mortalitas di seluruh dunia. Diperlukan inhibitor enzim $\alpha$-glukosidase yang berperan penting dalam metabolisme karbohidrat untuk menghindari hiperglikemia postprandial. Peptida bioaktif yang berasal dari protein kedelai dipilih sebagai alternatif pengobatan diabetes karena potensi terapeutiknya. Terdapat beberapa peptida bioaktif yang telah terbukti dapat menghambat enzim $\alpha$-glukosidase, seperti peptida bioaktif LLPLPVLK, SWLRL, dan WLRL. Penelitian ini bertujuan untuk mengidentifikasi dan mengevaluasi interaksi molekuler yang terjadi antara molekul peptida bioaktif dengan makromolekul enzim $\alpha$-glukosidase menggunakan motode penambatan molekuler berbasis protein-peptida secara in silico. Sekuensing peptida bioaktif terlebih dahulu dimodelkan dengan menggunakan perangkat lunak PEP-FOLD. Konformasi terbaik dipilih untuk dilakukan studi interaksi terhadap makromolekul enzim $\alpha$-glukosidase dengan menggunakan perangkat lunak HPEPDock. Eksplorasi lebih lanjut dilakukan terhadap interaksi molekuler yang terbentuk dengan menggunakan perangkat lunak BIOVIA Discovery Studio 2020. Berdasarkan hasil dari penambatan molekuler, peptida bioaktif WLRL memiliki afinitas yang paling baik terhadap enzim $\alpha$-glukosidase, yaitu dengan nilai energi bebas ikatan $-748,12 \mathrm{~kJ} / \mathrm{mol}$. Dengan demikian, peptida bioaktif tersebut diprediksi dapat digunakan sebagai kandidat inhibitor enzim $\alpha$-glukosidase. Kata Kunci: diabetes mellitus, enzim $\alpha$-glukosidase, peptida bioaktif, protein kedelai, studi in silico
\end{abstract}

\begin{abstract}
Diabetes mellitus is one of the endocrine metabolic disorders that has caused morbidity and mortality worldwide. A-glucosidase inhibitor which plays an important role in carbohydrate metabolism is needed to avoid postprandial hyperglycemia. A bioactive peptide derived from soy protein was chosen as an alternative treatment for diabetes because of its therapeutic potential. Several bioactive peptides have been shown to inhibit the $\alpha$-glucosidase enzyme, such as the bioactive peptide LLPLPVLK, SWLRL, and WLRL. This study aims to identify and evaluate molecular interactions that occur between bioactive peptide molecules and $\alpha$-glucosidase enzyme macromolecules using protein-peptide docking methods through in silico. Bioactive peptide sequencing was first modeled using the PEP-FOLD software. The best conformation was chosen for an interaction study of the $\alpha$-glucosidase enzyme macromolecule using HPEPDock software. Further exploration was carried out on the molecular interactions formed using BIOVIA Discovery Studio 2020 software. Based on the results of molecular docking, the WLRL bioactive peptide has the best affinity against the $\alpha$-glucosidase enzyme, with a binding free energy value of -748.12 $\mathrm{kJ} / \mathrm{mol}$. Therefore, the bioactive peptide is predicted to be a suitable candidate for the $\alpha$-glucosidase enzyme inhibitor.
\end{abstract}

Keywords: diabetes mellitus, $\alpha$-glucosidase enzyme, bioactive peptide, soy protein, in silico study

\section{PENDAHULUAN}

Diabetes mellitus (DM) adalah gangguan metabolisme kronis yang ditandai dengan disregulasi glukosa darah. Hingga saat ini,
DM merupakan masalah kesehatan global. Terdapat dua bentuk DM antara lain DM tipe 1 yang tergantung pada insulin (T1DM) sebanyak 10\% dari semua kasus DM, dan DM 
tipe 2 yang tidak tergantung pada insulin (T2DM) sebanyak 90\% dari semua kasus DM. Diperkirakan jumlah pasien yang mengalami diabetes akan meningkat dari 350 juta menjadi 592 juta pada tahun 2035 (Lee et al., 2016). Manajemen terapi T2DM biasanya melibatkan modifikasi gaya hidup dan terapi farmakologis. Beberapa obat yang digunakan untuk mengobati hiperglikemia pada T2DM, memiliki beberapa kekurangan, seperti biaya yang mahal dan memiliki efek samping serius (Qaseem et al., 2017). Efek samping dan toksisitas obat terapeutik menyebabkan banyaknya permintaan antidiabetik yang berasal dari senyawa alami karena dianggap lebih murah dan aman.

Enzim yang berhubungan dengan regulasi hiperglikemia postprandial, seperti $\alpha$ glukosidase, $\alpha$-amilase, dan dipeptidyl peptidase IV (DPP-IV), telah digunakan sebagai target terapi. $\alpha$-glukosidase merupakan enzim yang terikat membran dan terletak pada jaringan epitel usus kecil, berperan dalam pemecahan karbohidrat menjadi glukosa pada saluran pencernaan (Matsui et al., 1996). Penghambatan enzim ini telah diakui sebagai pendekatan yang efektif untuk menurunkan kadar glukosa darah (Johnson et al., 2011). a-glukosidase yang mengkatalisis reaksi dari dekstrin menjadi glukosa dalam usus kecil, memainkan peranan penting dalam sistem pencernaan dan penyerapan karbohidrat (Lee et al., 2013). Dengan demikian, inhibitor $\alpha$-glukosidase seperti acarbose, voglibose, dan miglitol secara efektif mengurangi hiperglikemia postprandial dengan menghambat metabolisme karbohidrat. Namun, inhibitor tersebut memiliki efek samping terhadap gastrointestinal. Kemudian, target terapi lainnya seperti dipeptidyl peptidase IV (DPPIV) diketahui dapat menyebabkan inaktivasi hormon incretin GLP-1 dan gastric inhibitory peptide (GIP) (Drucker, 2007).

Laporan Statistik Diabetes Nasional AS pada tahun 2017 mengungkapkan bahwa sekitar $73,6 \%$ orang dewasa dengan DM memiliki riwayat hipertensi yang dapat meningkatkan risiko penyakit jantung koroner (Abuissa et al., 2005), penyakit arteri perifer, stroke, dan bahkan penyakit ginjal. Selain itu, terdapat juga bukti yang menunjukkan bahwa diabetes dapat menyebabkan stres oksidatif sehingga produksi radikal bebas dapat melebihi kemampuan antioksidan tubuh (Asmat, Abad, \& Ismail, 2016). Oleh karena itu, diperlukan strategi pengobatan baru untuk mengatasi berbagai patologi dari penyakit ini.

Peptida bioaktif memiliki berbagai aktivitas fungsional, antara lain antimikroba, antihipertensi, aktivitas hipoglikemik, imunomodulasi, dan antioksidan. Karena memiliki berat molekul yang relatif lebih rendah maka absorbsivitas dan bioavailabilitasnya tinggi (Koopman et al., 2009). Peptida bioaktif telah terbukti berpotensi sebagai alternatif alami atau pelengkap obat sintetis. Berbagai penelitian telah menunjukkan efek hipoglikemik peptida bioaktif dari protein biji rami, ikan goby, dan protein kuning telur (Nasri et al., 2015; Ren et al., 2016; Zambrowicz et al., 2015).

Tujuan dari penelitian ini adalah untuk mengidentifikasi, mengevaluasi, dan mengeksplorasi aktivitas peptida bioaktif dari protein kedelai sebagai inhibitor enzim $\alpha$ glukosidase (Wang et al., 2019). Metode penambatan molekuler berbasis proteinpeptida digunakan untuk menjelaskan interaksi dengan afinitas terbaik dari peptida bioaktif sehingga diperoleh struktur molekul peptida acuan sebagai kandidat antidiabetik alami.

\section{METODE PENELITIAN \\ Makromolekul Enzim $\alpha$-glukosidase}

Makromolekul enzim yang digunakan dalam penelitian ini merupakan struktur kristal dari makromolekul enzim $\alpha$ glukosidase yang telah membentuk kompleks dengan acarbose. Makromolekul enzim tersebut diperoleh dari web Protein Data Bank (http://www.rcsb.org/pdb) dengan kode PDB 3W37 dan memiliki resolusi 1,70 A (Gambar 1) (Tagami et al., 2013). 


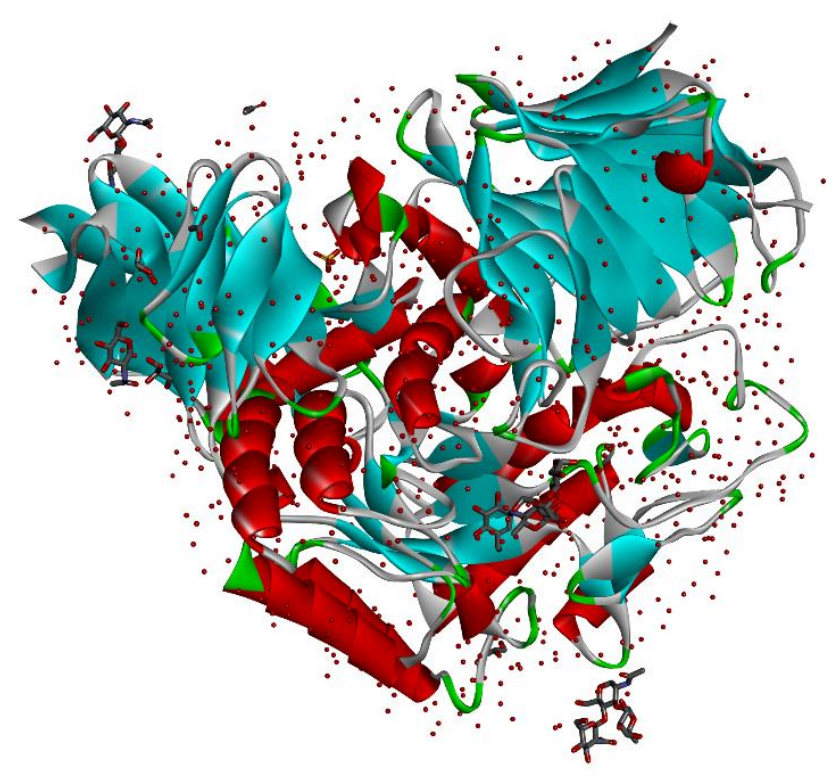

Gambar 1. Struktur kristal makromolekul enzim $\alpha$-glukosidase yang membentuk kompleks dengan acarbose

\section{Preparasi Makromolekul Enzim $\alpha$ - glukosidase \\ Struktur makromolekul enzim $\alpha$ - glukosidase yang telah diunduh sebelumnya dari web Protein Data Bank kemudian dipreparasi terlebih dahulu dengan menggunakan perangkat lunak MGLTools 1.5.6 yang dilengkapi dengan AutoDock 4.2. Preparasi makromolekul enzim ini dilakukan dengan menghilangkan molekul air dan acarose sebagai ligan alami yang terikat pada enzim $\alpha$-glukosidase, kemudian dilakukan penambahan atom hidrogen polar dan perhitungan muatan parsial Kollman (Kurniawan et al., 2018).}

\section{Identifikasi Sisi Aktif Makromolekul} Enzim $\alpha$-glukosidase

Makromolekul enzim $\alpha$-glukosidase yang telah dipreparasi selanjutnya diidentifikasi, dievaluasi, dan dieksplorasi bagian sisi aktif pengikatan yang berperan terhadap aktivitas antidiabetes dengan menggunakan perangkat lunak BIOVIA Discovery Studio 2020 (Kemmish et al., 2017; Norel et al., 2001). Acarbose yang berperan sebagai ligan alami dari makromolekul enzim $\alpha$-glukosidase digunakan untuk mengamati karakteristik dan sifat dari bagian sisi aktif makromolekul enzim tersebut (Fakih dan Dewi, 2020).

\section{Molekul Peptida Bioaktif}

Molekul peptida bioaktif yang digunakan dalam penelitian ini adalah tiga peptida bioaktif yang berasal dari protein kedelai dan telah dibuktikan melalui penelitian sebelumnya memiliki aktivitas terhadap enzim $\alpha$-glukosidase. Sekuensing dari ketiga molekul peptida bioaktif tersebut antara lain LLPLPVLK, SWLRL, dan WLRL (Wang et al., 2019).

\section{Pemodelan Molekul Peptida Bioaktif}

Pemodelan molekul dilakukan terhadap ketiga molekul peptida bioaktif dengan menggunakan perangkat lunak PEP-FOLD (http://bioserv.rpbs.univ-paris-diderot.fr/PEPFOLD/) (Gambar 2). PEP-FOLD merupakan suatu perangkat lunak yang digunakan untuk memodelkan sekuensing peptida bioaktif menjadi konformasi struktur 3D dengan memanfaatkan metode de novo (Thevenet et al., 2012; Shen et al., 2014).

\section{Penambatan Molekuler Berbasis Protein- Peptida}

Studi in silico dengan memanfaatkan metode penambatan molekuler berbasis 


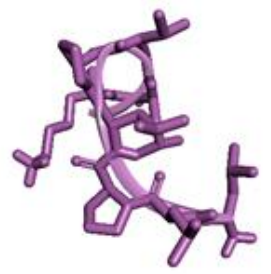

LLPLPVLK

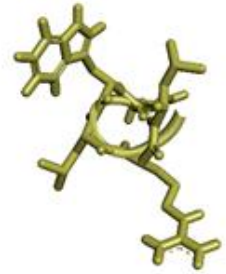

SWLRL

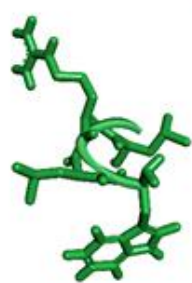

WLRL

Gambar 2. Pemodelan tiga dimensi sekuensing molekul peptida bioaktif yang berasal protein kedelai

protein-peptida dilakukan dengan menggunakan perangkat lunak HPEPDock untuk mengidentifikasi afinitas dan interaksi molekuler antara makromolekul enzim $\alpha$ glukosidase dengan ketiga molekul peptida bioaktif. Jarak antara permukaan makromolekul enzim dengan molekul peptida bioaktif dibatasi dengan radius maksimum 4.0 $\AA$ A. Beberapa parameter yang digunakan dalam metode ini antara lain berdasarkan representasi bentuk molekul, bagian sisi aktif pengikatan makromolekul enzim, serta pemilihan dan penilaian. Metode penambatan molekuler ini dilakukan secara efisien tanpa adanya ikatan yang bersifat rigid antar molekul (Zhou et al., 2018).

\section{Analisis Hasil Penambatan Molekuler Berbasis Protein-Peptida}

Tahapan identifikasi dan evaluasi dilakukan terhadap interaksi molekuler yang terjadi antara makromolekul enzim $\alpha$ glukosidase dengan ketiga molekul peptida bioaktif berdasarkan nilai energi bebas ikatan (Zhou et al., 2018). Pengamatan lebih lanjut dilakukan terhadap residu asam amino yang berperan dalam pembentukan interaksi molekuler pada bagian sisi aktif makromolekul enzim dengan menggunakan perangkat lunak BIOVIA Discovery Studio 2020.

\section{HASIL DAN PEMBAHASAN}

Studi penambatan molekuler digunakan untuk memprediksi orientasi pengikatan molekul kecil dan kandidat obat terhadap target protein untuk memprediksi afinitas dan aktivitasnya (Seeliger, Groot, \& De Pymol, 2010; Rauf, Zubair, \& Azhar, 2015). Dalam penelitian ini, dilakukan pemodelan peptida bioaktif yang berasal dari protein kedelai dan telah terbukti mampu menghambat enzim $\alpha$ glukosidase (Wang et al., 2019).

Kontrol glukosa merupakan pengobatan yang efektif untuk diabetes mellitus tipe II (Blonde, 2012; Zafar et al., 2016). Inhibitor enzim $\alpha$-glukosidase direkomendasikan untuk pasien diabetes untuk mengurangi hiperglikemia postprandial yang disebabkan oleh pemecahan molekul pati dalam usus kecil (Bolen et al., 2019). Penggunaan tanaman atau zat nabati dapat menjadi sumber yang sesuai dari inhibitor enzim $\alpha$-glukosidase karena harga dan toksisitas yang relatif rendah (Benalla, Bellahcen, \& Bnouham, 2010).

Makromolekul enzim $\alpha$-glukosidase yang dipilih sebagai target dipreparasi terlebih dahulu untuk memastikan agar molekul peptida bioaktif dapat membentuk interaksi yang stabil dengan makromolekul enzim. Selain itu, acarbose yang membentuk 


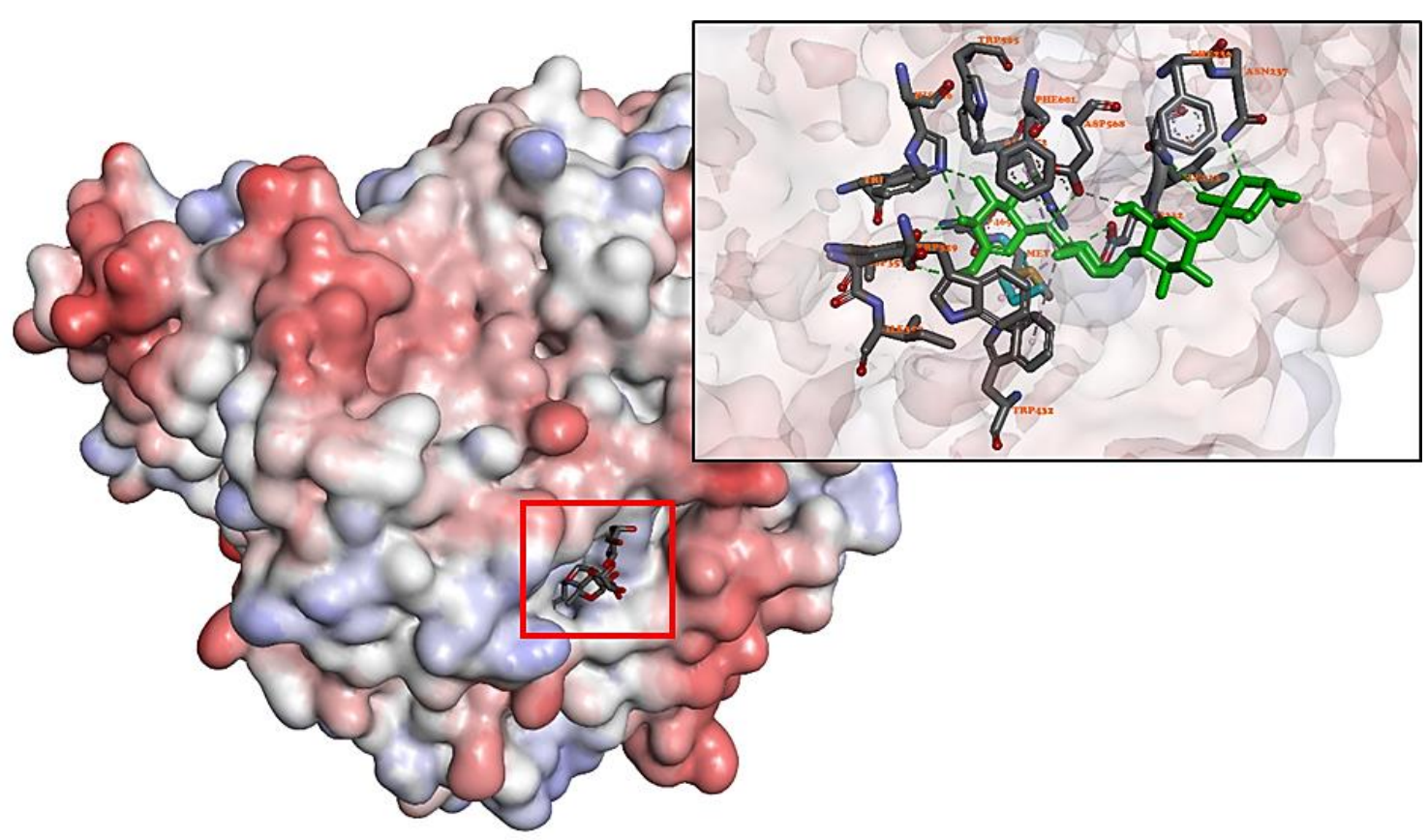

Gambar 3. Bagian sisi aktif pengikatan makromolekul enzim $\alpha$-glukosidase

kompleks dengan enzim $\alpha$-glukosidase digunakan sebagai molekul pembanding untuk mengamati interaksi dan afinitas yang paling baik.

Kemudian dilakukan identifikasi dan evaluasi dari bagian sisi aktif makromolekul enzim $\alpha$-glukosidase dengan menggunakan perangkat lunak BIOVIA Discovery Studio 2020 sehingga sifat dan karakteristik dari area pengikatan pada enzim tersebut dapat diketahui. Sebagaimana yang ditunjukkan pada Gambar 32 interaksi molekuler yang terbentuk antara enzim $\alpha$-glukosidase dengan acarbose terdiri dari 14 ikatan hidrogen (dengan Asp232, Ala234, Asn237, Asp357, Arg552, Asp568, dan His626) dan 3 interaksi hidrofobik (dengan Trp329, Trp432, dan Phe601). Dari hasil pengamatan tersebut maka dapat diprediksi bahwa residu asam amino tersebut berperan sebagai komponen penyusun dari bagian sisi aktif pengikatan makromolekul enzim $\alpha$-glukosidase.

Sekuensing peptida bioaktif kemudian dimodelkan menjadi struktur tiga dimensi dilakukan dengan menggunakan perangkat lunak PEP-FOLD. Hasil pemodelan molekul peptida bioaktif dengan konformasi terbaik dipilih berdasarkan energi sOPEP (Optimized Potential for Efficient Structure Prediction) (Thevenet et al., 2012; Shen et al., 2014). Energi sOPEP yang terintegrasi dalam perangkat lunak PEP-FOLD digunakan untuk menjelaskan bahwa struktur molekul peptida bioaktif yang dimodelkan telah mendekati keadaan aslinya dan mampu berinteraksi secara stabil dengan makromolekul enzim. Berdasarkan energi sOPEP yang terdapat pada Tabel 1 dapat diprediksi bahwa peptida

Tabel 1. Energi sOPEP (Optimized Potential for Efficient Structure Prediction) molekul peptida bioaktif hasil pemodelan tiga dimensi

\begin{tabular}{cc}
\hline Sekuensing peptida bioaktif & Energi sOPEP \\
\hline LLPLPVLK & $-28,76$ \\
SWLRL & $-18,71$ \\
WLRL & $-34,17$ \\
\hline
\end{tabular}


Tabel 2. Energi bebas pengikatan hasil penambatan molekuler berbasis protein-peptida

\begin{tabular}{cc}
\hline Molekul uji & Energi bebas ikatan $(\mathrm{kJ} / \mathrm{mol})$ \\
\hline Acarbose & $-203,59$ \\
LLPLPVLK & $-565,84$ \\
SWLRL & $-706,20$ \\
WLRL & $-748,12$ \\
\hline
\end{tabular}

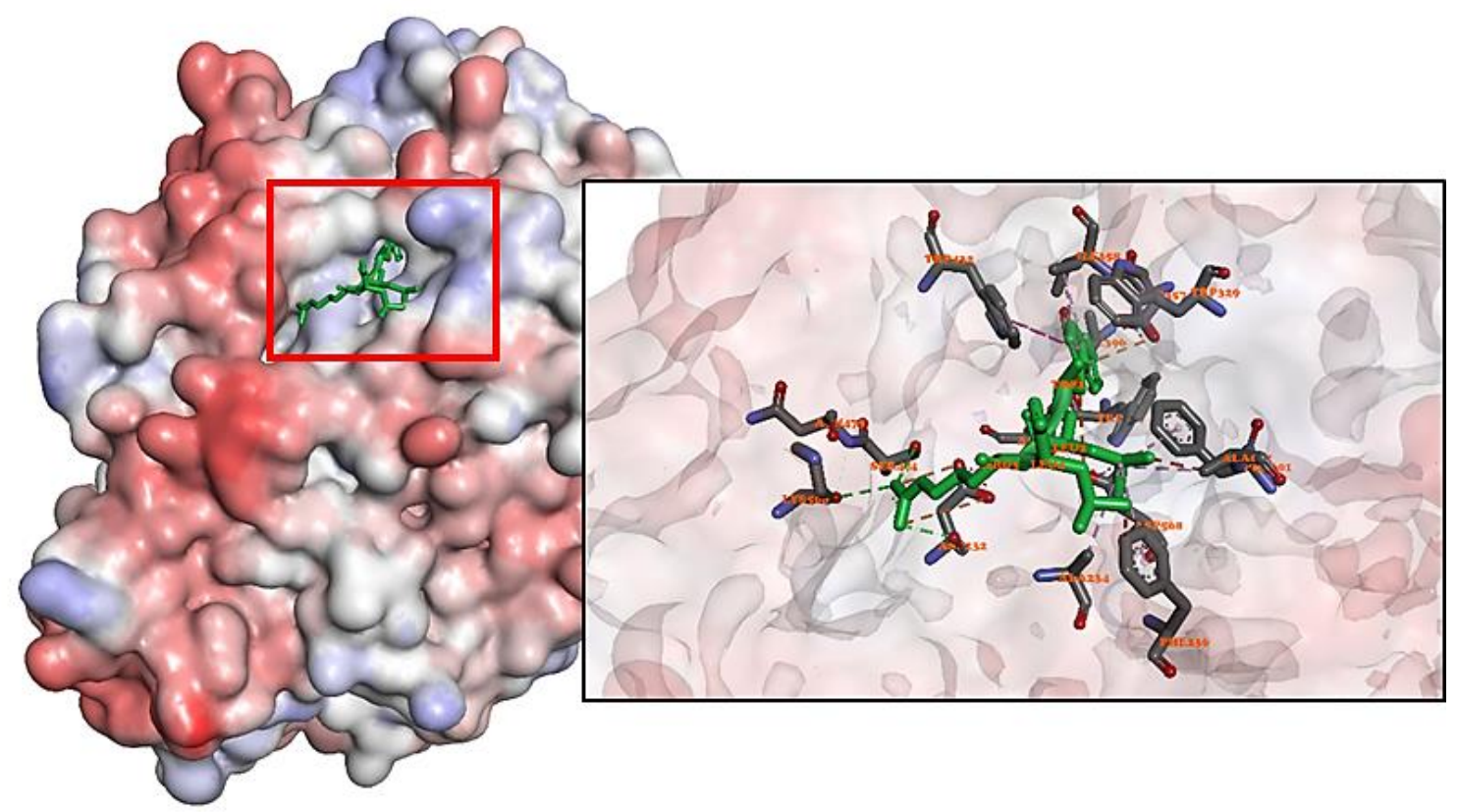

Gambar 4. Pose pengikatan molekul bioaktif WLRL dan interaksi yang terbentuk pada sisi aktif pengikatan makromolekul enzim $\alpha$-glukosidase

bioaktif tersebut akan mampu berikatan pada area sisi aktif pengikatan enzim $\alpha$ glukosidase.

Penambatan molekuler berbasis proteinpeptida dilakukan dengan menggunakan perangkat lunak HPEPDock untuk mengamati afinitas paling baik diantara ketiga molekul peptida bioaktif, serta mengidentifikasi dan mengevaluasi interaksi molekuler yang terjadi terhadap makromolekul enzim $\alpha$-glukosidase. Afinitas terbaik peptida bioaktif hasil penambatan molekuler dibandingkan berdasarkan nilai energi bebas ikatan (Zhou et al., 2018). Seperti yang ditunjukkan Tabel 2, molekul peptida bioaktif WLRL memiliki afinitas yang lebih baik apabila dibandingkan dengan peptida bioaktif lain dan acarbose, yaitu dengan nilai energi bebas ikatan $-748,12$ $\mathrm{kJ} / \mathrm{mol}$. Berdasarkan hal tersebut dapat diprediksi bahwa terdapat kemiripan lokasi tempat pengikatan antara peptida bioaktif WLRL dengan acarbose pada bagian sisi aktif pengikatan enzim $\alpha$-glukosidase (Zhou et al., 2018).

Selanjutnya, dilakukan identifikasi dan evalusi lebih lanjut terhadap visualisasi dari kompleks molekul peptida bioaktif dan makromolekul enzim $\alpha$-glukosidase. Gambar 4 menunjukkan bahwa peptida bioaktif WLRL memiliki interaksi yang lebih banyak dibandingkan peptida bioaktif lain. Interaksi yang terbentuk dari kompleks peptida bioaktif tersebut meliputi 3 ikatan hidrogen (dengan Asp232, Ser474, dan Lys506), 9 interaksi hidrofobik (dengan Ala234, Phe236, Ile358, Ile396, Trp432, Phe601, dan Ala602), dan 5 interaksi elektrostatik (dengan Asp232, Asp357, Asp469, dan Asp568). Dengan 
demikian, fenomena ini membuktikan bahwa afinitas paling baik yang ditunjukkan oleh peptida bioaktif WLRL karena adanya interaksi elektrostatik yang terbentuk pada bagian area sisi aktif dari makromolekul enzim $\alpha$-glukosidase.

\section{KESIMPULAN}

Melalui penelitian ini dapat dibuktikan bahwa peptida bioaktif WLRL mampu menghambat enzim melalui identifikasi dan evaluasi terhadap interaksi molekuler yang terbentuk dengan menggunakan metode penambatan molekuler berbasis proteinpeptida. Berdasarkan hasil penambatan molekuler diperoleh bahwa peptida bioaktif tersebut memiliki afinitas yang paling baik terhadap sisi aktif pengikatan makromolekul enzim $\alpha$-glukosidase yaitu dengan nilai energi bebas ikatan $-748,12 \mathrm{~kJ} / \mathrm{mol}$. Oleh karena itu, peptida bioaktif tersebut memiliki potensi sebagai kandidat inhibitor enzim $\alpha$ glukosidase untuk pengembangan antidiabetes.

\section{Daftar Pustaka}

Abuissa, H., Jones, P. G., Marso, S. P., and O’Keefe, J. H., 2005. Angiotensin-converting enzyme inhibitors or angiotensin receptor blockers for prevention of type 2 diabetes: A meta-analysis of randomized clinical trials. Journal of the American College of Cardiology, 46(5), pp.821-826.

Asmat, U., Abad, K., and Ismail, K., 2016. Diabetes mellitus and oxidative stress-A concise review. Saudi Pharmaceutical Journal, 24(5), pp.547-553.

Benalla, W., Bellahcen, S., and Bnouham, M., 2010. Antidiabetic Medicinal Plants as a Source of Alpha Glucosidase Inhibitors. Current Diabetes Reviews, 6(4), pp.247-254.

Blonde, L., 2012. Benefits and Risks for Intensive Glycemic Control in Patients With Diabetes Mellitus. The American Journal of the Medical Sciences, 343(1), pp.17-20.

Bolen, S., Feldman, L., Vassy, J., Wilson, L., and Yeh, H., 2019. Review Annals of Internal Medicine Systematic Review: Comparative Effectiveness and Safety of Oral Medications for Type 2 Diabetes Mellitus. Annals of Internal Medicine, 147(6), pp.386-399.

Drucker, D., 2007. Dipeptidyl peptidase-4 inhibition and the treatment of type 2 Diabetes. Diabetes Care, 30(6), pp.1335-1343.

Fakih, T. M, and Dewi, M. L., 2020. In silico Identification of Characteristics Spike Glycoprotein of SARS-CoV-2 in the Development Novel Candidates for COVID-19 Infectious Diseases. Journal of Biomedicine and Translational Research, 6(2), pp. 48-52.

Johnson, M. H., Lucius, A., Meyer, T., and Gonzalez De Mejia, E., 2011. Cultivar evaluation and effect of fermentation on antioxidant capacity and in vitro inhibition of $\alpha$-amylase and $\alpha$-glucosidase by highbush blueberry (Vaccinium corymbosum). Journal of Agricultural and Food Chemistry, 59(16), pp.8923-8930.

Lee, B. H., Yan, L., Phillips, R. J., Reuhs, B. L., Jones, K., Rose, D. R., Nichols, B. L., Quezada-Calvillo, R., Yoo, S. H., and Hamaker, B. R., 2013. Enzyme-Synthesized Highly Branched Maltodextrins Have Slow Glucose Generation at the Mucosal $\alpha$-Glucosidase Level and Are Slowly Digestible In Vivo. PLoS One, 8(4), e59745.

Lee, J. E., Min, S. H., Lee, D. H., Oh, T. J., Kim, K. M., Moon, J. H., and Lim, S, 2016. Comprehensive assessment of lipoprotein subfraction profiles according to glucose metabolism status, and association with insulin resistance in subjects with early-stage 
impaired glucose metabolism. International Journal of Cardiology, 225, pp.327-331.

Kemmish, H., Fasnacht, M., and Yan, L., 2017. Fully automated antibody structure prediction using BIOVIA tools: Validation study. PLoS One, 12, e0177923.

Koopman, R., Crombach, N., Gijsen, A. P., Walrand, S., Fauquant, J., Kies, A. K., and van Loon, L. J. C., 2009. Ingestion of a protein hydrolysate is accompanied by an accelerated in vivo digestion and absorption rate when compared with its intact protein. American Journal of Clinical Nutrition, 90(1), pp.106-115.

Kurniawan, F., Miura, Y., Kartasasmita, R. E., Yoshioka, N., Mutalib, A., and Tjahjono, D. H., 2018. In silico study, synthesis, and cytotoxic activities of porphyrin derivatives. Pharmaceuticals, 11, 8.

Matsui, T., Yoshimoto, C., Osajima, K., Oki, T., and Osajima, Y., 1996. In vitro survey of $\alpha$ glucosidase inhibitory food components. Bioscience, Biotechnology, and Biochemistry, 60(12), pp.2019-2022.

Nasri, R., Abdelhedi, O., Jemil, I., Daoued, I., Hamden, K., Kallel, C., and Karra-Châabouni, M., 2015. Ameliorating effects of goby fish protein hydrolysates on high-fat-high-fructose diet-induced hyperglycemia, oxidative stress and deterioration of kidney function in rats. Chemico-Biological Interactions, 242, pp.71-80.

Norel, R., Sheinerman, F., Petrey, D., and Honig, B., 2001. Electrostatic contributions to protein-protein interactions: Fast energetic filters for docking and their physical basis. Protein Sciences, 10(11), pp.2147-2161.

Qaseem, A., Barry, M. J., Humphrey, L. L., Forciea, M. A., Fitterman, N., Boyd, C., and Wilt, T. J., 2017. Oral pharmacologic treatment of type 2 diabetes mellitus: A clinical practice guideline update from the American college of physicians. Annals of Internal Medicine, 166(4), pp.279-290.

Rauf, M. A., Zubair, S., and Azhar, A., 2015. Ligand docking and binding site analysis with pymol and autodock/vina. International Journal of Basic and Applied Sciences, 4(2), pp.168-177.

Ren, Y., Liang, K., Jin, Y., Zhang, M., Chen, Y., Wu, H., and Lai, F., 2016. Identification and characterization of two novel $\alpha$-glucosidase inhibitory oligopeptides from hemp (Cannabis sativa L.) seed protein. Journal of Functional Foods, 26, pp.439-450.

Seeliger, D., Groot, B. L., and De Pymol, V., 2010. Ligand docking and binding site analysis with PyMOL and Autodock/Vina. Journal of Computer-Aided Molecular Design. 24(5), pp.417-422.

Shen, Y., Maupetit, J., Derreumaux, P., and Tuffery, P., 2014. Improved PEP-FOLD approach for peptide and miniprotein structure prediction. Journal of Chemical Theory and Computation, 10(10), pp.4745-4758.

Tagami, T., Yamashita, K., Okuyama, M., Mori, H., Yao, M., and Kimura, A., 2013. Molecular basis for the recognition of long-chain substrates by plant \& alpha-glucosidase. Journal of Biological Chemistry, 288(26), pp.19296-19303.

Veeraragavan, V., Narayanaswamy, R., and Chidambaram, R., 2017. Predicting the biodegradability nature of imidazole and its derivatives by modulating two histidine degradation enzymes (urocanase and formiminoglutamase) activities. Asian Journal 
Pharmaceutical and Clinical Research, 10(11), pp.383-386.

Wang, R., Zhao, H., Pan, X., Orfila, C., Lu, W., and Ma, Y., 2019. Preparation of bioactive peptides with antidiabetic, antihypertensive, and antioxidant activities and identification of $\alpha$-glucosidase inhibitory peptides from soy protein. Food Science and Nutrition. 7(5), pp.1848-1856.

Zafar, M., Khan, H., Rauf, A., Khan, A., and Lodhi, M. A., 2016. In Silico study of alkaloids as $\alpha$-glucosidase inhibitors: Hope for the Discovery of effective lead compounds. Frontiers in Endocrinology, 7, 153.

Zambrowicz, A., Pokora, M., Setner, B., Dąbrowska, A., Szołtysik, M., Babij, K., and Chrzanowska, J., 2015. Multifunctional peptides derived from an egg yolk protein hydrolysate: Isolation and characterization. Amino Acids, 47(2), pp.369-380.

Zhou, P., Jin, B., Li, H., and Huang, S. Y., 2018. HPEPDOCK: a web server for blind peptideprotein docking based on a hierarchical algorithm. Nucleic Acids Research, 46(1), pp.443450.

Zhou, P., Li, B., Yan, Y., Jin, B., Wang, L., and Huang, S. Y., 2018. Hierarchical Flexible Peptide Docking by Conformer Generation and Ensemble Docking of Peptides. Journal of Chemical Information and Modeling, 58(6), pp.1292-1302. 